\title{
Nonhuman Primate Optogenetics: Recent Advances and Future Directions
}

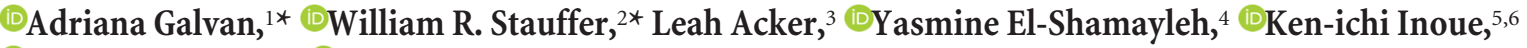 \\ (DShay Ohayon, ${ }^{7}$ and ${ }^{D}$ Michael C. Schmid ${ }^{8}$ \\ ${ }^{1}$ Yerkes National Primate Research Center and Department of Neurology, School of Medicine, Emory University, Atlanta, Georgia 30329, ${ }^{2}$ Department of \\ Neurobiology, University of Pittsburgh, Pittsburgh, Pennsylvania 15261, ${ }^{3}$ Department of Anesthesiology, Duke University Medical Center, Durham, North \\ Carolina 27710, ${ }^{4}$ Department of Physiology and Biophysics, Washington National Primate Research Center, University of Washington, Seattle, Washington \\ 98195, ${ }^{5}$ Department of Neuroscience, Primate Research Institute, Kyoto University, Inuyama, Aichi 484-8506, Japan, ${ }^{6}$ PRESTO, Japan Science and \\ Technology Agency, Kawaguchi, Saitama 332-0012, Japan, ${ }^{7}$ McGovern Institute for Brain Research, Brain and Cognitive Sciences, Massachusetts Institute \\ of Technology, Cambridge, Massachusetts 02139, and ${ }^{8}$ Institute of Neuroscience, Newcastle University, Newcastle, United Kingdom NE2 4HH
}

Optogenetics is the use of genetically coded, light-gated ion channels or pumps (opsins) for millisecond resolution control of neural activity. By targeting opsin expression to specific cell types and neuronal pathways, optogenetics can expand our understanding of the neural basis of normal and pathological behavior. To maximize the potential of optogenetics to study human cognition and behavior, optogenetics should be applied to the study of nonhuman primates (NHPs). The homology between NHPs and humans makes these animals the best experimental model for understanding human brain function and dysfunction. Moreover, for genetic tools to have translational promise, their use must be demonstrated effectively in large, wild-type animals such as Rhesus macaques. Here, we review recent advances in primate optogenetics. We highlight the technical hurdles that have been cleared, challenges that remain, and summarize how optogenetic experiments are expanding our understanding of primate brain function.

Key words: monkey; NHP; opsins; optogenetic; optrode; promoter

\section{Introduction}

Cognitive, motor, and sensory functions of the brain depend on coordinated interactions between connected neurons and networks. Abnormal activity patterns in functional brain networks are thought to underlie dysfunction in many brain diseases ranging from Parkinson's disease to schizophrenia. Optogenetics, the use of genetically coded, light-driven ion channels and pumps (opsins) to excite or inhibit neurons, enables fast and focused in vivo manipulation of neural activity. Optogenetic techniques have rapidly become the standard tool used to understand how cell types, circuits, and systems operate in normal and patholog-

Received Aug. 7, 2017; revised Sept. 29, 2017; accepted Oct. 2, 2017.

This work was supported by the National Institutes of Health (Grants P50NS098685, P510D011132, DP2MH113095-01, EY017292, 1R01DA029639, 1R01NS067199, R21EY024362, R01EY019258, R01EY023277, R01EY011378, P510D010425, and P30 EY01730), University of Pittsburgh Brain Institute (Start-Up funds to W.R.S.); the National Science Foundation (Graduate Research Fellowship Program to L.A.); National Defense Science and Engineering Graduate Fellowships (to L.A.); the Friends of McGovern Institute (to L.A.); the Japan Science and Technology Agency (PRESTO Grant JPMJPR1683, to K.I.); KAKENHI (Grants 15 H05879 and 17H05565, to K.I.); the Howard Hughes Medical Institute; the Life Sciences Research Foundation; the German Research Foundation (DFG Emmy Noether SCHM2806 to M.C.S.); and European Research Council (Optovision, to M.C.S.). We thank all those in our respective laboratories and our collaborators that contributed data and resources to the studies discussed in this review; our colleagues for constructive comments and discussions to parts of this manuscript, including Edward Boyden and Robert Desimone (L.A.), Gregory Horwitz (Y.E.S.), Masahiko Takada (K.I.), and Carsten Klein, Michael Ortiz-Rios, Beshoy Agayby, and Marcus Haag (M.C.S.); and Amber Torrise for developing the artwork in Figures 1 and 2.

${ }^{*}$ A.G. and W.R.S. contributed equally to this work.

Correspondence should be addressed to Adriana Galvan, PhD, Yerkes National Primate Research Center, Emory University, 954 Gatewood Road, NE, Atlanta, GA 30329. E-mail: agalvan@emory.edu.

DOI:10.1523/JNEUROSCI.1839-17.2017

Copyright $\odot 2017$ the authors $\quad 0270-6474 / 17 / 3710894-10 \$ 15.00 / 0$ ical states (Deisseroth, 2015). Recent breakthroughs using optogenetics have confirmed that phasic dopamine responses are teaching signals (Steinberg et al., 2013; Sharpe et al., 2017), shown that amygdala ensembles code for rewarding and aversive stimuli (Gore et al., 2015), and demonstrated that different cortical interneurons have distinct behavioral roles (Kvitsiani et al., 2013). Therefore, optogenetics is a valuable tool kit for investigating the link between brain and behavior. However, optogenetic experiments have been largely restricted to small animal models and the numerous differences between rodent and primate brains limit the generality of insights gained from these experiments. The anatomical, physiological, genetic, and behavioral characteristics of nonhuman primates (NHPs) are closer to the human than any other experimentally accessible species. These homologies make NHPs the best animal model for human brain functions and disorders (Phillips et al., 2014; Roelfsema and Treue, 2014). Applying optogenetics to study cell type-, circuit-, and system-level questions in NHPs promises to reveal fundamental mechanistic insights for human brain function and dysfunction.

The first NHP optogenetic studies used optical stimulation to activate neurons in primary motor cortex (M1) or frontal eye field (FEF) (Han et al., 2009; Diester et al., 2011). Subsequent studies provided evidence that optogenetics can be used to manipulate NHP behavior (Cavanaugh et al., 2012; Gerits et al., 2012; Jazayeri et al., 2012; Ohayon et al., 2013). Therefore, optogenetics was shown to modulate neuronal activity and behavior in NHPs. Since then, studies have started to provide new insights 
about function and dysfunction of specific brain circuits (Afraz et al., 2015; Inoue et al., 2015; Lu et al., 2015; Nassi et al., 2015b; Acker et al., 2016; Galvan et al., 2016; Klein et al., 2016; Stauffer et al., 2016; El-Shamayleh et al., 2017; Tamura et al., 2017). Despite these significant advances, the pace of NHP optogenetic studies is slowed by the current demand for tool development, modification, and improvement.

Optogenetic techniques have been modified and adapted to be used in NHP studies (Tamura et al., 2012; Ohayon et al., 2013; Ozden et al., 2013; Ruiz et al., 2013; Dai et al., 2015; YazdanShahmorad et al., 2016), yet several hurdles remain to make NHP optogenetics more effective and off-the-shelf, including the following:

\section{Targeting specific cell populations}

Genetic engineering is commonly used to achieve cell type- and pathway-specific optogenetics in transgenic mice (Gong et al., 2007). Transgenic NHPs are not widely available (Izpisua Belmonte et al., 2015), so viral vector delivery is the method of choice to deliver opsins to NHPs. However, current technology has a limited ability to direct cell type specificity.

\section{Brain size}

The anatomical and genetic differences between rodents and NHPs mean that the strategies used in rodent optogenetics are not always effective in NHPs. For example, given the larger size of macaque brains, the volume of tissue that should be engaged in optogenetic modulation is far greater.

\section{Minimizing tissue damage}

Research in NHPs benefits from using the same animal for multiple experiments, for example, in the context of assessing neuronal plasticity and the effects of learning. Therefore, reducing brain tissue damage inflicted by probe penetrations, viral injections, and light-induced heating is a priority.

\section{In vivo assessment of the time course and expression level of the opsins}

Currently, postmortem inspection is typically used to verify opsin expression, but in vivo assessment of expression levels would enhance the effectiveness of optogenetic manipulations in longer-lasting NHP experiments.

Addressing these challenges will advance primate neuroscience and hasten translation to medicine. Optogenetic techniques have the potential to be used in prosthetic devices or as an alternative to deep-brain stimulation (Busskamp et al., 2012; Chow and Boyden, 2013; Williams and Denison, 2013; Wykes et al., 2016). To maximize this translational potential, optogenetics should be broadly applicable in large, wild-type animals such as NHPs.

Here, we review recent breakthroughs in NHP optogenetics from our research groups (Fig. 1) and use these reports and others to demonstrate how some obstacles have been surpassed to give way to new scientific insights. Accordingly, this review is intended to provide a broad overview of the current state of the art. Readers are referred to more specialized publications about viral vector strategy (Gerits et al., 2015; El-Shamayleh et al., 2016; Mendoza et al., 2017), behavioral modulation (Kinoshita and Isa, 2015), and the use of NHPs (Galvan et al., 2017). The techniques currently used to gain genetic access to specific cell types, to deliver sufficient viral vector loads and light intensities, and to minimize tissue damage will lead the way toward safe, effective, and widespread use of optogenetics in NHP-based neuroscience re-

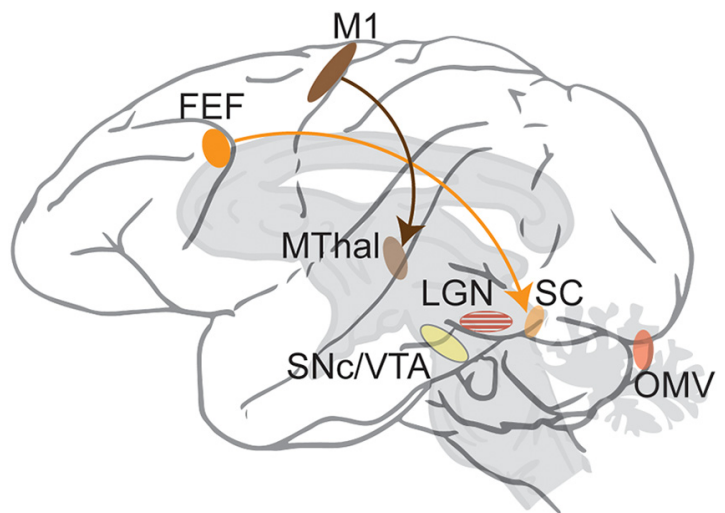

Figure 1. Recent advances in NHP optogenetics. Shown is a schematic outline of the macaque brain indicating the regions and pathways that are the focus of recent studies that use optogenetics. Colored ovals represent different brain nuclei and arrows represent connections between areas. M1, Primary motor cortex; FEF, Frontal eye field; LGN, lateral geniculate nucleus; SC, superior colliculus; MThal, Motor thalamus; SNc/VTA, substantia nigra pars compacta/ventral tegmental area; 0MV, oculomotor vermis.

search. In addition, these techniques can serve as a foundation for future circuit-based therapy options.

\section{Targeting Specific Neuronal Populations}

A significant roadblock to effective NHP optogenetics is the lack of universal tools such as genetically modified Cre-driver lines (Gong et al., 2007) for selective targeting of neuronal populations in NHPs. Efforts to circumvent this roadblock and achieve selective neuronal manipulations in monkeys can be broadly classified into two approaches: (1) those that use cell type specific gene promoters (Fig. 2A) and (2) those that use projection targeting. (Fig. $2 B-D$ ). Both approaches are based on the use of viral vectors to deliver opsin genes to neurons. In particular, adeno-associated virus (AAV) and lentivirus (LV) are commonly used because they are relatively safe and because they can infect nondividing cells such as neurons (Lentz et al., 2012; Kotterman et al., 2015).

The principal drawbacks to AAV and LV are their limited genetic capacities, $\sim 5$ and $\sim 9 \mathrm{~kb}$, respectively (Lentz et al., 2012). These limits require concise genetic sequences to control opsin expression. One approach is to isolate or synthesize small promoters. Several general purpose promoters are commonly used, including CMV and $\mathrm{Ef} 1 \alpha$, but viruses containing these promoters transduce a variety of cell types including neurons and glia (Yizhar et al., 2011).

\section{Targeting neuronal populations using cell type specific promoters}

Early breakthroughs have achieved cell type selectivity using viral vectors that carry small promoter sequences. The CaMKII $\alpha$ promoter has been often used in NHP experiments to target excitatory neurons (Han et al., 2009; Dai et al., 2014; Lu et al., 2015; Nassi et al., 2015a). Targeting NHP inhibitory interneurons is now within reach due to the development of $\mathrm{mDlx}$ enhancer elements (Dimidschstein et al., 2016). The tyrosine hydroxylase (TH) promoter has been used to label NHP dopamine neurons with GFP (Lerchner et al., 2014). Likewise, a promoter was developed to target D2-expressing medium spiny neurons in wild-type rodents (Zalocusky et al., 2016). These studies and others provide evidence that promoters can be used to direct cell type specific gene expression.

Three recent NHP studies have used cell type specific promoters to enable optogenetic investigation of well defined neuronal types and their role in brain function and behavior. These suc- 
cesses augur well for promoter-based targeting of specific cell types in the primate CNS.

\section{CaMKII $\alpha$ promoter for targeting}

koniocellular LGN cells

The CaMKII $\alpha$ promoter was used in macaque monkeys to target the well established projection from the lateral geniculate nucleus (LGN) to primary visual cortex (V1) (Klein et al., 2016). The laminar organization of primate LGN gives rise to three cell type-specific projection streams to $\mathrm{V} 1$, originating in konio-, magno-, and parvocellular neurons. Konio cells express the $\alpha$ subunit of the protein CaMKII (Hendry and Yoshioka, 1994), whereas the magno- and parvo-cellular neurons express parvalbumin (Yan et al., 1996). LGN konio neurons were successfully targeted using an AAV5CaMKII $\alpha$-ChR2-eYFP vector injected into the LGN of macaque monkeys. A significant number of cells were eYFP positive and the majority of these cells were $\mathrm{CaMKII} \alpha$ expressing neurons. However, there was also evidence for sparse labeling of other neuron types and of cells located outside of LGN, for example, in the retina or in V1, as a result of retrograde transport of vector particles to the distant cell bodies of neurons projecting to the injection site in LGN. Moreover, visual stimulation revealed that many of the optogenetically identified konio cells were not visually responsive. This result, in accordance with previous findings (Norton and Casagrande, 1982), suggested that other extraretinal signals could contribute to konio cell responses. Optogenetic stimulation of konio cell bodies in LGN evoked neuronal activity in V1. The resulting V1 laminar activation pattern was consistent with previous anatomical studies demonstrating the koniocellular projection to V1's supragranular layers (Norton and Casagrande, 1982; Hendry and Yoshioka, 1994; Chatterjee and Callaway, 2003).

\section{TH promoter for targeting dopaminergic neurons}

The TH promoter is active in dopamine neurons, where the gene product TH is a key enzyme catalyzing the synthesis of dopamine. To target dopamine neurons in Rhesus monkeys, a viral vector delivered the gene for the enzyme Cre recombinase under the control of a $300 \mathrm{bp} \mathrm{TH}$ promoter fragment. A second viral vector containing a double-floxed insert consisting of the gene for ChR2 driven by the ubiquitous Ef1 $\alpha$ promoter was injected with the TH-Cre virus (Stauffer et al., 2016). This strategy separated the demands of cell type specificity (determined by the small $\mathrm{TH}$ promoter) from the demand for high levels of ChR2 expression (determined by the Ef1 $\alpha$ promoter) and resulted in ChR2 expression in $\sim 40 \%$ of dopamine neurons. More importantly, the strategy produced highly specific expression; $>95 \%$ of ChR2expressing neurons were dopaminergic (Fig. $3 A$ ).

Optical stimulation was paired with liquid rewards to modulate reward value. Dopamine neurons responded more strongly to cues that predicted dopamine neuron-specific optogenetic stimulation at the time of the reward compared with cues that predicted reward alone (Fig. 4A). Larger dopamine responses reflect greater value, suggesting that the animal should choose the option that predicted stimulation (Lak et al., 2014; Stauffer et al., 2014). Indeed, animals readily learned which cue was associated with optogenetic reward stimulation and chose it with greater frequency (Fig. 4B). Therefore, dopamine neuron-specific optogenetic stimulation resulted in neuronal and behavioral correlates of value learning.

\section{L7 promoter for targeting cerebellar Purkinje cells}

The L7 gene and its promoter provide a compelling example of differential gene regulation across neuronal types and how this genetic foundation can be leveraged for cell type specific targeting in primates. Within the cerebellum, the L7 gene is active only in Purkinje cells and is silent in other cell types (Nordquist et al., 1988; Oberdick et al., 1988). The induction of L7 protein expression is coincident with the morphological structuring of Purkinje cell dendrites and synaptogenesis (Oberdick et al., 1988; Zhang et 

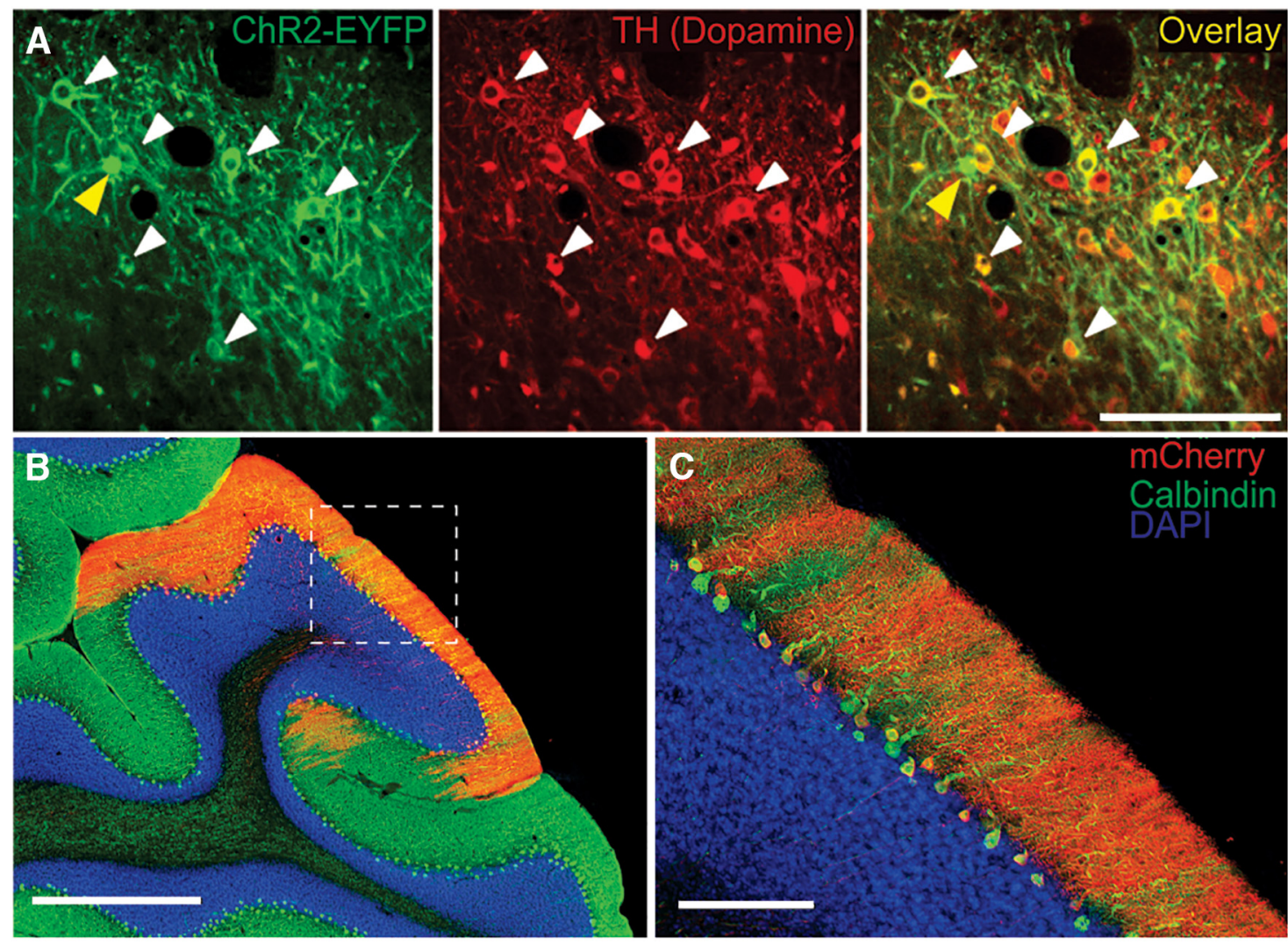

Figure 3. Cell type specific promoters direct expression of opsins in dopaminergic neurons and Purkinje cells in macaques. $A$, Expression of ChR2-EYFP (left) and TH (indicating dopaminergic neurons; middle). The majority of (hR2-EYFP-positive cells are also TH-positive, as indicated by white arrows. Yellow arrow indicates a rare example of nonspecific labeling. $\boldsymbol{B}$, Expression of ChR2-mCherry (red) is restricted to calbindin-positive (green) neurons. Calbindin is a reliable marker of cerebellar Purkinje cells. The region within the white square is shown at a higher magnification in C. Scale bars: $\boldsymbol{A}, 0.1 \mathrm{~mm} ; \boldsymbol{B}, 1 \mathrm{~mm} ; \boldsymbol{C}, 0.2 \mathrm{~mm}$. Reproduced with permission from Stauffer et al. (2016) (A) and El-Shamayleh et al. (2017) $(\boldsymbol{B}, \boldsymbol{C})$.

al., 2002). The L7 promoter is the basis for several lines of Purkinje cell-specific transgenic mice (Oberdick et al., 1988; Sługocka et al., 2017), but the earliest promoter sequence used to generate these animals was $8 \mathrm{~kb}$ long and thus too large to be used in AAV or LV vectors. Fortunately, subsequent systematic truncations of the full promoter sequence revealed that the minimal gene regulatory sequence required for Purkinje cell targeting $(\sim 1 \mathrm{~kb})$ is small enough to fit in these viral vectors (Oberdick et al., 1993).

One study used a murine L7 promoter sequence in AAV vectors (AAV1 and AAV9) to express ChR2 and achieve selective optogenetic control of Purkinje cells in Rhesus macaques (ElShamayleh et al., 2017). Immunohistochemical analyses revealed strong, Purkinje cell-specific ChR2 expression (91-96\% selective; Fig. $3 B$ ). To assess whether ChR2 expression driven by the L7 promoter could perturb primate Purkinje cell function in vivo, the effects of optical stimulation in cerebellar cortex were assessed electrophysiologically and behaviorally. Extracellular recordings at cerebellar cortical sites transduced with AAV-L7-ChR2 vectors demonstrated robust optogenetic activation, with spiking responses that entrained to sinusoidal laser modulation frequencies of up to $20 \mathrm{~Hz}$. Optical stimulation of the oculomotor vermis, a cerebellar cortical region involved in the execution of accurate saccades, caused consistent saccade dysmetria with a latency of $\sim 15 \mathrm{~ms}$. These results demonstrate the utility of AAV-L7-ChR2 vectors for investigating Purkinje cell-specific contributions to circuit function and behavior in primates.

These new studies collectively highlight the possibility of using cell type specific promoters to achieve opsin expression in tar- geted NHP neuronal populations and to manipulate NHP behavior with these selective perturbations of neuronal activity. The discovery and development of new and enhanced promoters will enable optogenetic manipulation in anatomically and behaviorally relevant neuronal populations of monkeys to approach the effectiveness of optogenetic manipulation in small, transgenic animals.

\section{Targeting neuronal populations based on their projections}

One critical advantage of optogenetics is the ability to perturb selectively the activity of neural pathways that connect two brain regions. Moreover, where cell type specific promoters are not available, projection targeting approaches can be used to gain cell type specificity. Pathway-selective optogenetic stimulation can be accomplished via anterograde, retrograde, or transsynaptic transport mechanisms (Fig. 2B-D) (Gradinaru et al., 2010; Stuber et al., 2011; Tye et al., 2011; Warden et al., 2012; El-Shamayleh et al., 2016). Anterograde projection targeting, in which opsins expressed at axonal terminals are activated locally, has been used to elucidate neural network functions in the primate brain (Inoue et al., 2015; Galvan et al., 2016).

\section{Anterograde projection targeting}

To manipulate selectively the projection from the FEF to the superior colliculus (SC), an AAV-CMV-ChR2 vector was injected into the FEF and a fiber optic was inserted into the SC to illuminate ChR2-expressing axon terminals of FEF neurons (Inoue et al., 2015). Many SC neurons were excited by optical stimulation of FEF axon terminals. Optical stimulation of axon 
terminals often evoked saccadic eye movements toward response fields corresponding to the stimulation sites in the SC (Fig. 4C,D; Inoue et al., 2015). This result was in contrast to activation of cell bodies in the FEF, where optical stimulation decreased reaction time but rarely evoked saccades unless paired with electrical stimulation (Gerits et al., 2012; Ohayon et al., 2013). This suggests that the cell selectivity achieved via projection targeting can result in strong behavioral effects.

Pathway-selective stimulation after anterograde transport of opsins has also been used to study corticothalamic motor circuits in NHPs. AAV-CaMKII $\alpha$-ChR2 or AAV-CaMKII $\alpha$-C1V1 was injected into the motor cortices. Optogenetic activation of corticothalamic terminals modulated activity in ventral motor thalamus neurons (Galvan et al., 2016). In contrast to the shorter latency excitations described in the oculomotor pathway (Inoue et al., 2015), selective optogenetic activation of corticothalamic terminals resulted in long-latency and complex physiological responses of motor thalamic neurons, suggesting a modulatory role for cortical afferents in the primate motor thalamus.

\section{Retrograde projection targeting}

Retrograde transport capabilities can be used to achieve cell type and pathwayselective optogenetic control (Kato et al., 2011; Oyibo et al., 2014; Tervo et al., 2016; Tanabe et al., 2017). In these cases, viral particles enter axon terminals at the injection site and are then transported along the axon back to the cell body, where the transgene will be transcribed. Efforts are currently ongoing to test the efficacy of several varieties of retrograde viruses in NHPs, including LVs with modified glycoproteins such as Fug-B, FugB2, Fug-E, and Tloop (Kato et al., 2011; Hirano et al., 2013; Cetin and Callaway, 2014; Kobayashi et al., 2016; Tanabe et al., 2017), herpes simplex virus (Neve et al., 2005; Fenno et al., 2014), canine adeno virus type 2 (Soudais et al., 2001; Salinas et al., 2009; Junyent and Kremer, 2015), AAV serotypes with endogenous retrograde properties (Rothermel et al., 2013), and designer AAVs with engineered retrograde capabilities (Tervo et al., 2016). One study showed that an optimized chimeric envelope glycoprotein (FuG-E) greatly accentuates the efficacy of retrograde gene delivery of a pseudotyped LV vector in the primate brain. Striatal injection of the FuG-E-GFP vector-labeled neurons in regions that project to the striatum, including cerebral cortex, thalamus, and substantia nigra (Tanabe et al., 2017).

\section{Transsynaptic targeting}

Transsynaptic transport of viral particles or gene products holds the promise to create widespread yet circuit-specific labeling to investigate large-scale brain networks. In this case, the viral particles or gene products will travel anterogradely to the axon terminals or retrogradely to the soma, where they will cross the synapse to be incorporated into connected neurons (Gradinaru
B
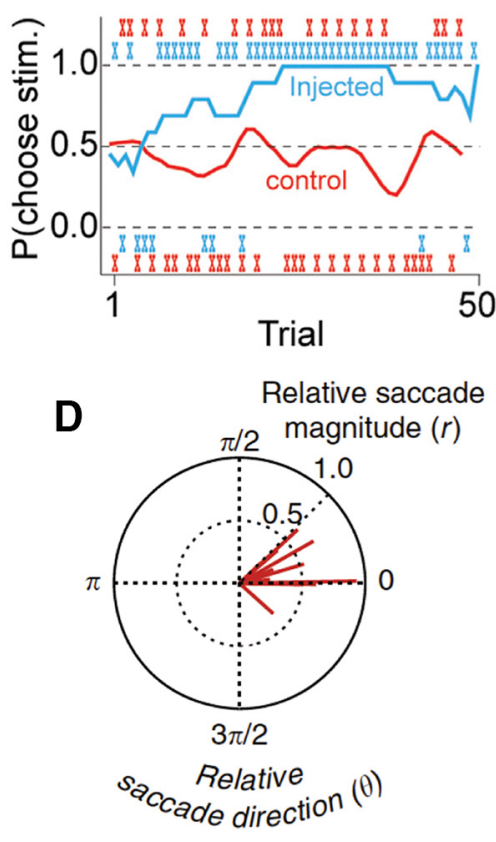

Figure 4. Neuronal and behavioral correlates of optical stimulation applied to specific neuronal populations. $A, B$, Neuronal and behavioral correlates of stimulating dopamine neurons. $\boldsymbol{A}$, Inset, Blue visual cue predicted liquid reward along with laser stimula(bottom) demonstrate that opticalical stimulation and a cue that predicted reward stimulation (top) or option associated with reward alone (bottom). Lines represent moving averages (sliding window with 10 steps) of the two choice sets. C, D, Neuronal and behavioral correlates of FEF to SC pathway stimulation. C, PSTH of SC neuronal

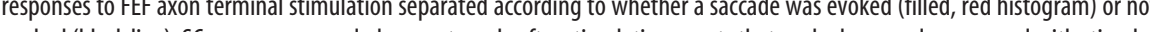
tions that did not evoke a saccade. $D$, Polar plot of the magnitude $(r)$ and direction $(\theta)$ of optogenetically evoked saccades. Red lines indicate the averaged vector of evoked saccades at each stimulation site $(n=15)$. Saccade toward center of response field is represented by $r=1.0, \theta=0$. Reproduced with permission from Stauffer et al. (2016) $(\boldsymbol{A}, \boldsymbol{B})$ and Inoue et al. $(2015)(\boldsymbol{C}, \boldsymbol{D})$.

et al., 2010; Nassi et al., 2015a). An important consideration is that the retrograde spread may extend beyond one synapse. The potential benefit is that using a transsynaptic vector will provide optogenetic control over multisynaptic circuits, but the peril is that some commonly used transsynaptic viruses are cytotoxic (Nassi et al., 2015a). In rodents, some AAV serotypes (AAV1 and AAV9) show anterograde transsynaptic transduction properties (Zingg et al., 2017) that can be exploited along with Credependent expression to identify and modulate specific neuronal pathways. Further engineering of transsynaptic vectors to reduce toxicity and enhance transgene expression (Nassi and Callaway, 2007; Oyibo et al., 2014) will broaden their use in NHP optogenetic experiments. Using novel viral vectors to achieve selective opsin expression based on synaptic connectivity would be particularly advantageous for studying large-scale brain networks in NHPs.

\section{Brain Size}

Rhesus macaque brains are 200 times larger than mouse brains and contain two orders of magnitude more neurons (HerculanoHouzel, 2009). Therefore, a larger number of neurons should be engaged for optogenetic modulation of NHP behavior compared with rodent experiments. To achieve this, NHP optogenetic stud- 
ies require opsin expression across large brain areas, opsins with enhanced light sensitivity, and broad light delivery. High levels of opsin expression across large brain areas can be achieved by using enhanced viral vector delivery techniques and selecting viral vector types that diffuse easily through brain tissue. MRI guidance and convection enhanced infusion have been applied successfully to deliver large volumes of viral vectors to precise locations in the NHP brain (Bankiewicz et al., 2000; Yazdan-Shahmorad et al., 2016). Similarly, LV and AAV viral vector subtypes can be selected to maximize the spread of the viral solution and transduction of neurons (Gerits et al., 2015; El-Shamayleh et al., 2016).

Light is absorbed as it propagates in the brain. Oxygenated hemoglobin is the major source of visible light absorption in living brain tissue and red light is the least absorbed visible wavelength spectrum (Eggert and Blazek, 1987; Robles et al., 2010). In vivo measurements from rodent cortex at a depth of $1.5 \mathrm{~mm}$ showed that five times as much red light remained unabsorbed compared with green or blue light (Acker et al., 2016). Therefore, next generation opsins that are activated preferentially by wavelengths closer to the red spectrum, including VChR1 (Zhang et al., 2008), C1V1 (Yizhar et al., 2011), Jaws (Chuong et al., 2014), Chrimson (Klapoetke et al., 2014), ReaChR (Lin et al., 2013), and BReaChES (Rajasethupathy et al., 2015), show promise for largevolume tissue modulation in primates. C1V1 stimulation of principal neurons in somatosensory cortex in macaques is sufficient to elicit a sensation (May et al., 2014), a finding that could be exploited to mimic sensory stimulation when sensory functions have been compromised (e.g., in the development of neuroprostheses for stroke or spinal cord injury). Research with C1V1 opsins, along with multielectrode arrays, revealed spatiotemporal dynamics in the monkey motor cortical networks (Lu et al., 2015). Likewise, C1V1 opsins have been used to test the computational properties of V1 neurons (Nassi et al., 2015b) and to demonstrate that optogenetic activation of the lateral intraparietal area can bias eye movements during a visuospatial discrimination task (Dai et al., 2014).

Light must be delivered more broadly in primates than in rodents to affect functionally relevant neuronal populations. Indeed, some of the early failures to observe behavioral effects of optogenetic stimulation in FEF (Han et al., 2009) have been overcome by improving light delivery (Gerits et al., 2012; Acker et al., 2016). Strategies to increase the extent of brain tissue illuminated include the use of probes that combine multiple fibers (Tamura et al., 2012) or optic fibers with a tapered end (Dai et al., 2015; Acker et al., 2016, 2017).

In one study, an improved optrode combined with the redshifted inactivating opsin Jaws inhibited $>90 \%$ of macaque FEF neurons over a $10 \mathrm{~mm}^{3}$ tissue volume (Acker et al., 2016). This result is comparable to the volumes inactivated in cortical cooling (Chafee and Goldman-Rakic, 2000) and pharmacological inactivation studies (Sommer and Tehovnik, 1997; Tehovnik and Sommer, 1997; Martin and Ghez, 1999). The optogenetic inactivation was effective at low light intensities and resulted in large behavioral changes (Acker et al., 2016). Therefore, the use of enhanced light delivery and red-shifted opsins to perturb large populations of neurons renders optogenetic manipulations more effective at modulating NHP behavior.

\section{Minimizing Tissue Damage}

In optogenetic experiments, tissue can be damaged by lightinduced heating and repeated probe insertion. Limiting excessive tissue heating is essential because cortical temperature increases of $>4^{\circ} \mathrm{C}$ may induce damage. Moreover, temperature increases could result in unwanted side effects such as neuronal firing increases in some heat-sensitive brain areas in response to $>2{ }^{\circ} \mathrm{C}$ temperature increases (Kiyatkin and Brown, 2004; Kiyatkin, 2004; Kiyatkin, 2005, 2007). Illumination-induced heterogeneous neuronal firing patterns can be effectively eliminated by monitoring tissue heating and limiting light power to avoid a $>1^{\circ} \mathrm{C}$ temperature increase (Acker et al., 2016).

Although experiments in superficial cortical regions can be performed through optical windows using noninvasive light sources (Ruiz et al., 2013; Yazdan-Shahmorad et al., 2016), studies of deep cortical layers or subcortical structures require repeated probe insertion, with consequent tissue damage. There is a tradeoff between fiber outer diameter and tissue damage. Thicker fibers deliver more light but increase tissue damage induced by probe insertion, especially in acute experiments. Furthermore, when combined recordings and stimulation are desired, the traditional approach of using optrodes fabricated by gluing a fiber to an electrode might induce greater damage because these probes are prone to shearing and cutting brain tissue.

There has been steady progress in developing multishank and coaxial probes (Abaya et al., 2012; Wang et al., 2012; Chen et al., 2013; Ozden et al., 2013; Lee et al., 2015; Naughton et al., 2016) that minimizes these problems. The use of tapered-end fibers results in reduced brain damage compared with optical fibers with a blunt end (Dai et al., 2015; Acker et al., 2016, 2017; Pisanello et al., 2017; Tamura et al., 2017). An alternative to the repeated optrode penetrations is the use of chronically implanted multielectrode arrays that incorporate an optic fiber for opsin activation (Lu et al., 2015), or micro-electrocorticographic laminar arrays for cortical surface recordings (Yazdan-Shahmorad et al., 2016).

Looking toward translational approaches may further inspire engineering innovations in primate optogenetics. For example, when laser thermal ablation is used to treat otherwise inoperable brain tumors and epileptogenic foci in human patients, repeated penetrations are avoided, if possible, to minimize penetration damage (Missios et al., 2015). Further, in proportion to total brain size, the diameter of optical fibers currently in use for human thermotherapy, $\sim 600 \mu \mathrm{m}$ (Norred and Johnson, 2014), is less than that used in NHPs (about 200-400 $\mu \mathrm{m}$ for optrodes). During human surgeries, the temperature of surrounding tissue during laser ablation is monitored to minimize collateral tissue damage (Missios et al., 2015). Based on current laser use in human neurosurgery, reasonable future directions for NHP optogenetics many include temperature monitoring, chronic or semichronic light probes to limit repeated penetrations, and reductions in illuminator/electrode diameter.

\section{In Vivo Assessment of the Temporal Course and Expression Level of the Opsins}

Currently, most researchers depend on postmortem histological examination to confirm the correct targeting of brain regions or cell types and level of opsin expression. Ideally, a noninvasive in vivo method would monitor opsin expression after virus injections and before starting functional experiments. If the opsins are expressed in neurons inhabiting superficial cortical layers, imaging of the fluorescent reporter can be used to gauge opsin expression through optical windows (Ruiz et al., 2013). For subcortical structures, fluorescence can be detected in vivo using an optic fiber positioned in the injected area (Diester et al., 2011; Tamura et al., 2012; Ozden et al., 2013; Tamura et al., 2017). This method is encumbered by the damage inflected on the tissue by probe 
insertion, but may be preferable to postmortem verification. As an example, in one study of the role of the perirhinal cortex in behavioral judgements of object semantic value, researchers used a multifiber optogenetic probe that provided improved light delivery, minimized tissue damage, and monitored opsin expression (Tamura et al., 2017).

A radically different approach to minimizing tissue damage and assessing transgene expression is to pursue an all-optical interrogation (AOI) strategy (Rickgauer et al., 2014; Emiliani et al., 2015). AOI involves coexpression of an activity reporter gene (e.g., GCaMP) and an actuator (e.g., red-shifted opsin) and the use of a single optical probe to image and perturb activity. AOI has several advantages over traditional electrophysiology. First, a much larger set of neurons can be monitored simultaneously compared with single electrode or even multishank probes. Second, it is possible to identify activity arising from specific neurons reliably. Third, structured illumination patterns can be applied to study local connectivity and dynamics. AOI experiments in rodents have used gradient refractive index (GRIN) lenses (Ghosh et al., 2011; Ziv et al., 2013), but at the cost of significant tissue damage above the region of interest (i.e., brain aspiration; Barretto and Schnitzer, 2012), which may not be acceptable in studies involving NHPs. Furthermore, commonly available GRIN lenses are $2-5 \mathrm{~mm}$ in length, not long enough to reach deep subcortical regions in NHPs. A recent study tested a new microendoscope design consisting of ultrathin multimode optical fibers that are 5-10 times thinner than commercially available GRIN lenses and have no length constraint (Ohayon et al., 2017). These fibers are of the same type as those traditionally used in NHP optogenetic experiments (Diester et al., 2011) and fiber photometry (Gunaydin et al., 2014; Kim et al., 2016). However, in contrast to fiber photometry, this new design allows for full image reconstruction beneath the fiber down to a micron-scale resolution. Furthermore, it allows the delivery of light patterns (structured light) at the fiber tip for precise stimulation of only a subset of neurons in the field of view. Ongoing experiments are under way to test this technology in NHPs and make it accessible for end users.

\section{Conclusion}

Human perception, action, and cognition are largely dependent on specialized brain networks that arose during the evolution of primates. This specialization renders NHPs, especially Old World monkeys such as Rhesus macaques, an invaluable animal model with which to investigate human brain function. Modern neuroscience has been reshaped by game-changing technologies including optogenetics and genetically coded calcium indicators that are most effectively applied to transgenic animals. Although transgenic Rhesus macaques have been created successfully (Yang et al., 2008; Liu et al., 2016), economic considerations and the long generation time may limit the utility of transgenic Old-World monkeys in neuroscientific research. Moreover, the successful implementation of emerging (optogenetic) technologies in wildtype macaques will provide a rich foundation for the translational application of circuit-based therapy to humans. Therefore, developing methods to facilitate the application of genetic techniques for controlling and monitoring neural activity in NHPs is one the most critical challenges in modern neuroscience.

Recent studies have achieved effective application of optogenetics to NHPs by demonstrating cell type specific expression using gene promoters, selective projection targeting, improved light delivery, and opsins with improved light sensitivity. As reviewed here, cell type specific promoters have been used to study the function of konio cells in the LGN, dopamine neurons in the midbrain, and Purkinje cells in the cerebellum (Fig. 3). The use of cell type specific promoters brings NHP neuroscience one step closer to the capabilities of transgenic mouse studies. Moving forward, the development or discovery of new regulatory sequences that confer selective expression in a wide array of neuronal types will be one of the greatest challenges that we face. Most genes are expressed in many cell types, rather than being cell type specific. Moreover, it is not clear how conserved noncoding transcriptional regulatory regions are, so it is not clear which mouse promoters will be effective in monkeys (Suzuki et al., 2004). To advance the field, studies in which promoters can be screened or engineered in a high-throughput fashion may hold the key to unlocking a wider array of cell type specific promoters (PortalesCasamar et al., 2010; Schlabach et al., 2010; Rajkumar and Maerkl, 2012; Smith et al., 2013).

Projection targeting, which does not rely on cell type specific promoters, but rather relies on anterograde trafficking of opsins or retrograde transport of viral particles (Fig. 2), has already been used to reveal the functional roles of motor control networks (Inoue et al., 2015; Galvan et al., 2016). New viral vectors with selective and improved retrograde transport properties present an opportunity to photo-identify cells that project to a region of interest. This technology will make it feasible to record selectively from afferent neurons and discover how neural circuits process information. Moreover, a likely contributor to the absence of observed behavioral correlates in early optogenetic experiments is coactivation of competing neuronal populations that cancel each other's effect. It may be possible, therefore, to increase the size of observed behavioral effects by increasing cell type selectivity. Indeed, targeting specific neuronal populations, whether via gene promoter or pathway tracing, has resulted in sizable behavioral effects after optical stimulation (Fig. 4) (Inoue et al., 2015; Stauffer et al., 2016; El-Shamayleh et al., 2017). These advances bode well for the future of investigating neural signals and their relationship to well controlled behaviors in NHPs.

Traditionally, similar optical probes were used to deliver light in mice and monkeys despite the fact that the monkey brain is two orders of magnitude larger than that of the mouse. By combining light delivery probes that have tapered endings with red-shifted opsins, large volumes of brain tissue $\left(\sim 10 \mathrm{~mm}^{3}\right)$ can be illuminated by a single probe (Acker et al., 2016, 2017). Moreover, because probes with tapered ends reduce the damage caused by probe insertions, multiple probes can be inserted, maximizing the chance to (in-)activate entire monkey brain regions.

In summary, we are substantially closer to optogenetics being applied in NHPs as effectively as it is applied in rodents. Further progress in NHP optogenetic experiments and translation to human medicine will depend on the rapid dissemination of technical advances and setbacks faced in the course of these experiments. Indeed, given the larger expenses and time needed for primate experiments relative to other species, communication of negative or incremental findings in optogenetic (or similar) techniques may be particularly beneficial for the NHP research community. The new developments reviewed here highlight the value of primate optogenetics to reveal the mechanistic insights into the brain circuits that support perception, action, and cognition and how their dysfunction gives rise to human pathologies.

\section{References}

Abaya TV, Blair S, Tathireddy P, Rieth L, Solzbacher F (2012) A 3D glass optrode array for optical neural stimulation. Biomed Opt Express 3:30873104. CrossRef Medline 
Acker L, Pino EN, Boyden ES, Desimone R (2016) FEF inactivation with improved optogenetic methods. Proc Natl Acad Sci U S A 113:E7297E7306. CrossRef Medline

Acker LC, Pino EN, Boyden ES, Desimone R (2017) Large volume illumination for optogenetics in non-human primates. J Vis Exp 128:e56330. CrossRef

Afraz A, Boyden ES, DiCarlo JJ (2015) Optogenetic and pharmacological suppression of spatial clusters of face neurons reveal their causal role in face gender discrimination. Proc Natl Acad Sci U S A 112:6730-6735. CrossRef Medline

Bankiewicz KS, Eberling JL, Kohutnicka M, Jagust W, Pivirotto P, Bringas J, Cunningham J, Budinger TF, Harvey-White J (2000) Convectionenhanced delivery of AAV vector in parkinsonian monkeys; in vivo detection of gene expression and restoration of dopaminergic function using pro-drug approach. Exp Neurol 164:2-14. CrossRef Medline

Barretto RP, Schnitzer MJ (2012) In vivo microendoscopy of the hippocampus. Cold Spring Harb Protoc 2012:1092-1099. CrossRef Medline

Busskamp V, Picaud S, Sahel JA, Roska B (2012) Optogenetic therapy for retinitis pigmentosa. Gene Ther 19:169-175. CrossRef Medline

Cavanaugh J, Monosov IE, McAlonan K, Berman R, Smith MK, Cao V, Wang KH, Boyden ES, Wurtz RH (2012) Optogenetic inactivation modifies monkey visuomotor behavior. Neuron 76:901-907. CrossRef Medline

Cetin A, Callaway EM (2014) Optical control of retrogradely infected neurons using drug-regulated "TLoop" lentiviral vectors. J Neurophysiol 111: 2150-2159. CrossRef Medline

Chafee MV, Goldman-Rakic PS (2000) Inactivation of parietal and prefrontal cortex reveals interdependence of neural activity during memoryguided saccades. J Neurophysiol 83:1550-1566. Medline

Chatterjee S, Callaway EM (2003) Parallel colour-opponent pathways to primary visual cortex. Nature 426:668-671. CrossRef Medline

Chen S, Pei W, Gui Q, Chen Y, Zhao S, Wang H, Chen H (2013) A fiberbased implantable multi-optrode array with contiguous optical and electrical sites. J Neural Eng 10:046020. CrossRef Medline

Chow BY, Boyden ES (2013) Optogenetics and translational medicine. Sci Transl Med 5:177ps175. CrossRef Medline

Chuong AS, et al. (2014) Noninvasive optical inhibition with a red-shifted microbial rhodopsin. Nat Neurosci 17:1123-1129. CrossRef Medline

Dai J, Brooks DI, Sheinberg DL (2014) Optogenetic and electrical microstimulation systematically bias visuospatial choice in primates. Curr Biol 24:63-69. CrossRef Medline

Dai J, Ozden I, Brooks DI, Wagner F, May T, Agha NS, Brush B, Borton D, Nurmikko AV, Sheinberg DL (2015) Modified toolbox for optogenetics in the nonhuman primate. Neurophotonics 2:031202. CrossRef Medline

Deisseroth K (2015) Optogenetics: 10 years of microbial opsins in neuroscience. Nat Neurosci 18:1213-1225. CrossRef Medline

Diester I, Kaufman MT, Mogri M, Pashaie R, Goo W, Yizhar O, Ramakrishnan C, Deisseroth K, Shenoy KV (2011) An optogenetic toolbox designed for primates. Nat Neurosci 14:387-397. CrossRef Medline

Dimidschstein J, et al. (2016) A viral strategy for targeting and manipulating interneurons across vertebrate species. Nat Neurosci 19:1743-1749. CrossRef Medline

Eggert HR, Blazek V (1987) Optical properties of human brain tissue, meninges, and brain tumors in the spectral range of 200 to $900 \mathrm{~nm}$. Neurosurgery 21:459-464. CrossRef Medline

El-Shamayleh Y, Ni AM, Horwitz GD (2016) Strategies for targeting primate neural circuits with viral vectors. J Neurophysiol 116:122-134. CrossRef Medline

El-Shamayleh Y, Kojima Y, Soetedjo R, Horwitz GD (2017) Selective optogenetic control of purkinje cells in monkey cerebellum. Neuron 95:5162.e4. CrossRef Medline

Emiliani V, Cohen AE, Deisseroth K, Häusser M (2015) All-optical interrogation of neural circuits. J Neurosci 35:13917-13926. CrossRef Medline

Fenno LE, Mattis J, Ramakrishnan C, Hyun M, Lee SY, He M, Tucciarone J, Selimbeyoglu A, Berndt A, Grosenick L, Zalocusky KA, Bernstein H, Swanson H, Perry C, Diester I, Boyce FM, Bass CE, Neve R, Huang ZJ, Deisseroth K (2014) Targeting cells with single vectors using multiplefeature Boolean logic. Nat Methods 11:763-772. CrossRef Medline

Galvan A, Hu X, Smith Y, Wichmann T (2016) Effects of optogenetic activation of corticothalamic terminals in the motor thalamus of awake monkeys. J Neurosci 36:3519-3530. CrossRef Medline

Galvan A, Caiola MJ, Albaugh DL (2017) Advances in optogenetic and che- mogenetic methods to study brain circuits in non-human primates. J Neural Transm (Vienna), in press.

Gerits A, Farivar R, Rosen BR, Wald LL, Boyden ES, Vanduffel W (2012) Optogenetically induced behavioral and functional network changes in primates. Curr Biol 22:1722-1726. CrossRef Medline

Gerits A, Vancraeyenest P, Vreysen S, Laramée ME, Michiels A, Gijsbers R, Van den Haute C, Moons L, Debyser Z, Baekelandt V, Arckens L, Vanduffel W (2015) Serotype-dependent transduction efficiencies of recombinant adeno-associated viral vectors in monkey neocortex. Neurophotonics 2:031209. CrossRef Medline

Ghosh KK, Burns LD, Cocker ED, Nimmerjahn A, Ziv Y, Gamal AE, Schnitzer MJ (2011) Miniaturized integration of a fluorescence microscope. Nat Methods 8:871-878. CrossRef Medline

Gong S, Doughty M, Harbaugh CR, Cummins A, Hatten ME, Heintz N, Gerfen CR (2007) Targeting Cre recombinase to specific neuron populations with bacterial artificial chromosome constructs. J Neurosci 27: 9817-9823. CrossRef Medline

Gore F, Schwartz EC, Brangers BC, Aladi S, Stujenske JM, Likhtik E, Russo MJ, Gordon JA, Salzman CD, Axel R (2015) Neural representations of unconditioned stimuli in basolateral amygdala mediate innate and learned responses. Cell 162:134-145. CrossRef Medline

Gradinaru V, Zhang F, Ramakrishnan C, Mattis J, Prakash R, Diester I, Goshen I, Thompson KR, Deisseroth K (2010) Molecular and cellular approaches for diversifying and extending optogenetics. Cell 141:154-165. CrossRef Medline

Gunaydin LA, Grosenick L, Finkelstein JC, Kauvar IV, Fenno LE, Adhikari A, Lammel S, Mirzabekov JJ, Airan RD, Zalocusky KA, Tye KM, Anikeeva P, Malenka RC, Deisseroth K (2014) Natural neural projection dynamics underlying social behavior. Cell 157:1535-1551. CrossRef Medline

Han X, Qian X, Bernstein JG, Zhou HH, Franzesi GT, Stern P, Bronson RT, Graybiel AM, Desimone R, Boyden ES (2009) Millisecond-timescale optical control of neural dynamics in the nonhuman primate brain. Neuron 62:191-198. CrossRef Medline

Hendry SH, Yoshioka T (1994) A neurochemically distinct third channel in the macaque dorsal lateral geniculate nucleus. Science 264:575-577. CrossRef Medline

Herculano-Houzel S (2009) The human brain in numbers: a linearly scaled-up primate brain. Front Hum Neurosci 3:31. CrossRef Medline

Hirano M, Kato S, Kobayashi K, Okada T, Yaginuma H, Kobayashi K (2013) Highly efficient retrograde gene transfer into motor neurons by a lentiviral vector pseudotyped with fusion glycoprotein. PLoS One 8:e75896. CrossRef Medline

Inoue K, Takada M, Matsumoto M (2015) Neuronal and behavioural modulations by pathway-selective optogenetic stimulation of the primate oculomotor system. Nat Commun 6:8378. CrossRef Medline

Izpisua Belmonte JC, et al. (2015) Brains, genes, and primates. Neuron 86: 617-631. CrossRef Medline

Jazayeri M, Lindbloom-Brown Z, Horwitz GD (2012) Saccadic eye movements evoked by optogenetic activation of primate V1. Nat Neurosci 15:1368-1370. CrossRef Medline

Junyent F, Kremer EJ (2015) CAV-2: why a canine virus is a neurobiologist's best friend. Curr Opin Pharmacol 24:86-93. CrossRef Medline

Kato S, Kuramochi M, Takasumi K, Kobayashi K, Inoue K, Takahara D, Hitoshi S, Ikenaka K, Shimada T, Takada M, Kobayashi K (2011) Neuron-specific gene transfer through retrograde transport of lentiviral vector pseudotyped with a novel type of fusion envelope glycoprotein. Hum Gene Ther 22:1511-1523. CrossRef Medline

Kim CK, Yang SJ, Pichamoorthy N, Young NP, Kauvar I, Jennings JH, Lerner TN, Berndt A, Lee SY, Ramakrishnan C, Davidson TJ, Inoue M, Bito H, Deisseroth K (2016) Simultaneous fast measurement of circuit dynamics at multiple sites across the mammalian brain. Nat Methods 13:325328. CrossRef Medline

Kinoshita M, Isa T (2015) Potential of optogenetics for the behavior manipulation of non-human primates. In: Optogenetics: light-sensing proteins and their applications (Yawo H, Kandori H, Koizumi A, eds), pp 279290. Tokyo: Springer Japan.

Kiyatkin EA (2004) Brain hyperthermia during physiological and pathological conditions: causes, mechanisms, and functional implications. Curr Neurovasc Res 1:77-90. CrossRef Medline

Kiyatkin EA (2005) Brain hyperthermia as physiological and pathological phenomena. Brain Res Brain Res Rev 50:27-56. CrossRef Medline 
Kiyatkin EA (2007) Physiological and pathological brain hyperthermia. Prog Brain Res 162:219-243. CrossRef Medline

Kiyatkin EA, Brown PL (2004) Modulation of physiological brain hyperthermia by environmental temperature and impaired blood outflow in rats. Physiol Behav 83:467-474. CrossRef Medline

Klapoetke NC, et al. (2014) Independent optical excitation of distinct neural populations. Nat Methods 11:338-346. CrossRef Medline

Klein C, Evrard HC, Shapcott KA, Haverkamp S, Logothetis NK, Schmid MC (2016) Cell-targeted optogenetics and electrical microstimulation reveal the primate koniocellular projection to supra-granular visual cortex. Neuron 90:143-151. CrossRef Medline

Kobayashi K, Kato S, Inoue K, Takada M, Kobayashi K (2016) Altering entry site preference of lentiviral vectors into neuronal cells by pseudotyping with envelope glycoproteins. Methods Mol Biol 1382:175-186. CrossRef Medline

Kotterman MA, Chalberg TW, Schaffer DV (2015) Viral vectors for gene therapy: translational and clinical outlook. Annu Rev Biomed Eng 17:6389. CrossRef Medline

Kvitsiani D, Ranade S, Hangya B, Taniguchi H, Huang JZ, Kepecs A (2013) Distinct behavioural and network correlates of two interneuron types in prefrontal cortex. Nature 498:363-366. CrossRef Medline

Lak A, Stauffer WR, Schultz W (2014) Dopamine prediction error responses integrate subjective value from different reward dimensions. Proc Natl Acad Sci U S A 111:2343-2348. CrossRef Medline

Lee J, Ozden I, Song YK, Nurmikko AV (2015) Transparent intracortical microprobe array for simultaneous spatiotemporal optical stimulation and multichannel electrical recording. Nat Methods 12:1157-1162. CrossRef Medline

Lentz TB, Gray SJ, Samulski RJ (2012) Viral vectors for gene delivery to the central nervous system. Neurobiol Dis 48:179-188. CrossRef Medline

Lerchner W, Corgiat B, Der Minassian V, Saunders RC, Richmond BJ (2014) Injection parameters and virus dependent choice of promoters to improve neuron targeting in the nonhuman primate brain. Gene Ther 21: 233-241. CrossRef Medline

Lin JY, Knutsen PM, Muller A, Kleinfeld D, Tsien RY (2013) ReaChR: a red-shifted variant of channelrhodopsin enables deep transcranial optogenetic excitation. Nat Neurosci 16:1499-1508. CrossRef Medline

Liu Z, et al. (2016) Autism-like behaviours and germline transmission in transgenic monkeys overexpressing MeCP2. Nature 530:98-102. CrossRef Medline

Lu Y, Truccolo W, Wagner FB, Vargas-Irwin CE, Ozden I, Zimmermann JB, May T, Agha NS, Wang J, Nurmikko AV (2015) Optogenetically induced spatiotemporal gamma oscillations and neuronal spiking activity in primate motor cortex. J Neurophysiol 113:3574-3587. CrossRef Medline

Martin JH, Ghez C (1999) Pharmacological inactivation in the analysis of the central control of movement. J Neurosci Methods 86:145-159. CrossRef Medline

May T, Ozden I, Brush B, Borton D, Wagner F, Agha N, Sheinberg DL, Nurmikko AV (2014) Detection of optogenetic stimulation in somatosensory cortex by non-human primates: towards artificial tactile sensation. PLoS One 9:e114529. CrossRef Medline

Mendoza SD, El-Shamayleh Y, Horwitz GD (2017) AAV-mediated delivery of optogenetic constructs to the macaque brain triggers humoral immune responses. J Neurophysiol 117:2004-2013. CrossRef Medline

Missios S, Bekelis K, Barnett GH (2015) Renaissance of laser interstitial thermal ablation. Neurosurg Focus 38:E13. CrossRef Medline

Nassi JJ, Callaway EM (2007) Specialized circuits from primary visual cortex to V2 and area MT. Neuron 55:799-808. CrossRef Medline

Nassi JJ, Cepko CL, Born RT, Beier KT (2015a) Neuroanatomy goes viral! Front Neuroanat 9:80. CrossRef Medline

Nassi JJ, Avery MC, Cetin AH, Roe AW, Reynolds JH (2015b) Optogenetic activation of normalization in alert macaque visual cortex. Neuron 86: 1504-1517. CrossRef Medline

Naughton JR, Connolly T, Varela JA, Lundberg J, Burns MJ, Chiles TC, Christianson JP, Naughton MJ (2016) Shielded coaxial optrode arrays for neurophysiology. Front Neurosci 10:252. CrossRef Medline

Neve RL, Neve KA, Nestler EJ, Carlezon WA Jr (2005) Use of herpes virus amplicon vectors to study brain disorders. Biotechniques 39:381-391. CrossRef Medline

Nordquist DT, Kozak CA, Orr HT (1988) cDNA cloning and characterization of three genes uniquely expressed in cerebellum by Purkinje neurons. J Neurosci 8:4780-4789. Medline
Norred SE, Johnson JA (2014) Magnetic resonance-guided laser induced thermal therapy for glioblastoma multiforme: a review. Biomed Res Int 2014:761312. CrossRef Medline

Norton TT, Casagrande VA (1982) Laminar organization of receptive-field properties in lateral geniculate nucleus of bush baby (Galago crassicaudatus). J Neurophysiol 47:715-741. Medline

Oberdick J, Levinthal F, Levinthal C (1988) A Purkinje cell differentiation marker shows a partial DNA sequence homology to the cellular sis/ PDGF2 gene. Neuron 1:367-376. CrossRef Medline

Oberdick J, Schilling K, Smeyne RJ, Corbin JG, Bocchiaro C, Morgan JI (1993) Control of segment-like patterns of gene expression in the mouse cerebellum. Neuron 10:1007-1018. CrossRef Medline

Ohayon S, Grimaldi P, Schweers N, Tsao DY (2013) Saccade modulation by optical and electrical stimulation in the macaque frontal eye field. J Neurosci 33:16684-16697. CrossRef Medline

Ohayon S, Caravaca Aguirre AM, Piestun R, DiCarlo JJ (2017) Deep brain fluorescence imaging with minimally invasive ultra-thin optical fibers. bioRxiv. CrossRef

Oyibo HK, Znamenskiy P, Oviedo HV, Enquist LW, Zador AM (2014) Long-term Cre-mediated retrograde tagging of neurons using a novel recombinant pseudorabies virus. Front Neuroanat 8:86. CrossRef Medline

Ozden I, Wang J, Lu Y, May T, Lee J, Goo W, O’Shea DJ, Kalanithi P, Diester I, Diagne M, Deisseroth K, Shenoy KV, Nurmikko AV (2013) A coaxial optrode as multifunction write-read probe for optogenetic studies in nonhuman primates. J Neurosci Methods 219:142-154. CrossRef Medline

Phillips KA, Bales KL, Capitanio JP, Conley A, Czoty PW, 't Hart BA, Hopkins WD, Hu SL, Miller LA, Nader MA, Nathanielsz PW, Rogers J, Shively CA, Voytko ML (2014) Why primate models matter. Am J Primatol 76:801827. CrossRef Medline

Pisanello F, Mandelbaum G, Pisanello M, Oldenburg IA, Sileo L, Markowitz JE, Peterson RE, Della Patria A, Haynes TM, Emara MS, Spagnolo B, Datta SR, De Vittorio M, Sabatini BL (2017) Dynamic illumination of spatially restricted or large brain volumes via a single tapered optical fiber. Nat Neurosci 20:1180-1188. CrossRef Medline

Portales-Casamar E, et al. (2010) A regulatory toolbox of MiniPromoters to drive selective expression in the brain. Proc Natl Acad Sci U S A 107: 16589-16594. CrossRef Medline

Rajasethupathy P, Sankaran S, Marshel JH, Kim CK, Ferenczi E, Lee SY, Berndt A, Ramakrishnan C, Jaffe A, Lo M, Liston C, Deisseroth K (2015) Projections from neocortex mediate top-down control of memory retrieval. Nature 526:653-659. CrossRef Medline

Rajkumar AS, Maerkl SJ (2012) Rapid synthesis of defined eukaryotic promoter libraries. ACS Synth Biol 1:483-490. CrossRef Medline

Rickgauer JP, Deisseroth K, Tank DW (2014) Simultaneous cellularresolution optical perturbation and imaging of place cell firing fields. Nat Neurosci 17:1816-1824. CrossRef Medline

Robles FE, Chowdhury S, Wax A (2010) Assessing hemoglobin concentration using spectroscopic optical coherence tomography for feasibility of tissue diagnostics. Biomed Opt Express 1:310-317. CrossRef Medline

Roelfsema PR, Treue S (2014) Basic neuroscience research with nonhuman primates: a small but indispensable component of biomedical research. Neuron 82:1200-1204. CrossRef Medline

Rothermel M, Brunert D, Zabawa C, Díaz-Quesada M, Wachowiak M (2013) Transgene expression in target-defined neuron populations mediated by retrograde infection with adeno-associated viral vectors. J Neurosci 33:15195-15206. CrossRef Medline

Ruiz O, Lustig BR, Nassi JJ, Cetin A, Reynolds JH, Albright TD, Callaway EM, Stoner GR, Roe AW (2013) Optogenetics through windows on the brain in the nonhuman primate. J Neurophysiol 110:1455-1467. CrossRef Medline

Salinas S, Bilsland LG, Henaff D, Weston AE, Keriel A, Schiavo G, Kremer EJ (2009) CAR-associated vesicular transport of an adenovirus in motor neuron axons. PLoS Pathog 5:e1000442. CrossRef Medline

Schlabach MR, Hu JK, Li M, Elledge SJ (2010) Synthetic design of strong promoters. Proc Natl Acad Sci U S A 107:2538-2543. CrossRef Medline

Sharpe MJ, Chang CY, Liu MA, Batchelor HM, Mueller LE, Jones JL, Niv Y, Schoenbaum G (2017) Dopamine transients are sufficient and necessary for acquisition of model-based associations. Nat Neurosci 20:735-742. CrossRef Medline

Sługocka A, Wiaderkiewicz J, Barski JJ (2017) Genetic targeting in cerebellar purkinje cells: an update. Cerebellum 16:191-202. CrossRef Medline

Smith RP, Riesenfeld SJ, Holloway AK, Li Q, Murphy KK, Feliciano NM, 
Orecchia L, Oksenberg N, Pollard KS, Ahituv N (2013) A compact, in vivo screen of all 6-mers reveals drivers of tissue-specific expression and guides synthetic regulatory element design. Genome Biol 14:R72. CrossRef Medline

Sommer MA, Tehovnik EJ (1997) Reversible inactivation of macaque frontal eye field. Exp Brain Res 116:229-249. CrossRef Medline

Soudais C, Laplace-Builhe C, Kissa K, Kremer EJ (2001) Preferential transduction of neurons by canine adenovirus vectors and their efficient retrograde transport in vivo. FASEB J 15:2283-2285. Medline

Stauffer WR, Lak A, Schultz W (2014) Dopamine reward prediction error responses reflect marginal utility. Curr Biol 24:2491-2500. CrossRef Medline

Stauffer WR, Lak A, Yang A, Borel M, Paulsen O, Boyden ES, Schultz W (2016) Dopamine neuron-specific optogenetic stimulation in Rhesus macaques. Cell 166:1564-1571.e6. CrossRef Medline

Steinberg EE, Keiflin R, Boivin JR, Witten IB, Deisseroth K, Janak PH (2013) A causal link between prediction errors, dopamine neurons and learning. Nat Neurosci 16:966-973. CrossRef Medline

Stuber GD, Sparta DR, Stamatakis AM, van Leeuwen WA, Hardjoprajitno JE, Cho S, Tye KM, Kempadoo KA, Zhang F, Deisseroth K, Bonci A (2011) Excitatory transmission from the amygdala to nucleus accumbens facilitates reward seeking. Nature 475:377-380. CrossRef Medline

Suzuki Y, Yamashita R, Shirota M, Sakakibara Y, Chiba J, Mizushima-Sugano J, Nakai K, Sugano S (2004) Sequence comparison of human and mouse genes reveals a homologous block structure in the promoter regions. Genome Res 14:1711-1718. CrossRef Medline

Tamura K, Ohashi Y, Tsubota T, Takeuchi D, Hirabayashi T, Yaguchi M, Matsuyama M, Sekine T, Miyashita Y (2012) A glass-coated tungsten microelectrode enclosing optical fibers for optogenetic exploration in primate deep brain structures. J Neurosci Methods 211:49-57. CrossRef Medline

Tamura K, Takeda M, Setsuie R, Tsubota T, Hirabayashi T, Miyamoto K, Miyashita Y (2017) Conversion of object identity to object-general semantic value in the primate temporal cortex. Science 357:687-692. CrossRef Medline

Tanabe S, Inoue KI, Tsuge H, Uezono S, Nagaya K, Fujiwara M, Kato S, Kobayashi K, Takada M (2017) The use of an optimized chimeric envelope glycoprotein enhances the efficiency of retrograde gene transfer of a pseudotyped lentiviral vector in the primate brain. Neurosci Res 120:4552. CrossRef Medline

Tehovnik EJ, Sommer MA (1997) Effective spread and timecourse of neural inactivation caused by lidocaine injection in monkey cerebral cortex. J Neurosci Methods 74:17-26. CrossRef Medline

Tervo DG, Hwang BY, Viswanathan S, Gaj T, Lavzin M, Ritola KD, Lindo S, Michael S, Kuleshova E, Ojala D, Huang CC, Gerfen CR, Schiller J, Dudman JT, Hantman AW, Looger LL, Schaffer DV, Karpova AY (2016) A designer AAV variant permits efficient retrograde access to projection neurons. Neuron 92:372-382. CrossRef Medline

Tye KM, Prakash R, Kim SY, Fenno LE, Grosenick L, Zarabi H, Thompson KR, Gradinaru V, Ramakrishnan C, Deisseroth K (2011) Amygdala circuitry mediating reversible and bidirectional control of anxiety. Nature 471:358-362. CrossRef Medline
Wang J, Wagner F, Borton DA, Zhang J, Ozden I, Burwell RD, Nurmikko AV, van Wagenen R, Diester I, Deisseroth K (2012) Integrated device for combined optical neuromodulation and electrical recording for chronic in vivo applications. J Neural Eng 9:016001. CrossRef Medline

Warden MR, Selimbeyoglu A, Mirzabekov JJ, Lo M, Thompson KR, Kim SY, Adhikari A, Tye KM, Frank LM, Deisseroth K (2012) A prefrontal cortex-brainstem neuronal projection that controls response to behavioural challenge. Nature 492:428-432. CrossRef Medline

Williams JC, Denison T (2013) From optogenetic technologies to neuromodulation therapies. Sci Transl Med 5:177ps176. CrossRef Medline

Wykes RC, Kullmann DM, Pavlov I, Magloire V (2016) Optogenetic approaches to treat epilepsy. J Neurosci Methods 260:215-220. CrossRef Medline

Yan YH, Winarto A, Mansjoer I, Hendrickson A (1996) Parvalbumin, calbindin, and calretinin mark distinct pathways during development of monkey dorsal lateral geniculate nucleus. J Neurobiol 31:189-209. Medline

Yang SH, Cheng PH, Banta H, Piotrowska-Nitsche K, Yang JJ, Cheng EC, Snyder B, Larkin K, Liu J, Orkin J, Fang ZH, Smith Y, Bachevalier J, Zola SM, Li SH, Li XJ, Chan AW (2008) Towards a transgenic model of Huntington's disease in a non-human primate. Nature 453:921-924. CrossRef Medline

Yazdan-Shahmorad A, Diaz-Botia C, Hanson TL, Kharazia V, Ledochowitsch P, Maharbiz MM, Sabes PN (2016) A large-scale interface for optogenetic stimulation and recording in nonhuman primates. Neuron 89:927939. CrossRef Medline

Yizhar O, Fenno LE, Prigge M, Schneider F, Davidson TJ, O’Shea DJ, Sohal VS, Goshen I, Finkelstein J, Paz JT, Stehfest K, Fudim R, Ramakrishnan C, Huguenard JR, Hegemann P, Deisseroth K (2011) Neocortical excitation/inhibition balance in information processing and social dysfunction. Nature 477:171-178. CrossRef Medline

Zalocusky KA, Ramakrishnan C, Lerner TN, Davidson TJ, Knutson B, Deisseroth K (2016) Nucleus accumbens D2R cells signal prior outcomes and control risky decision-making. Nature 531:642-646. CrossRef Medline

Zhang F, Prigge M, Beyrière F, Tsunoda SP, Mattis J, Yizhar O, Hegemann P, Deisseroth K (2008) Red-shifted optogenetic excitation: a tool for fast neural control derived from Volvox carteri. Nat Neurosci 11:631-633. CrossRef Medline

Zhang X, Zhang H, Oberdick J (2002) Conservation of the developmentally regulated dendritic localization of a Purkinje-cell-specific mRNA that encodes a G-protein modulator: comparison of rodent and human Pcp2(L7) gene structure and expression. Brain Res Mol Brain Res 105:110. CrossRef Medline

Zingg B, Chou XL, Zhang ZG, Mesik L, Liang F, Tao HW, Zhang LI (2017) AAV-mediated anterograde transsynaptic tagging: mapping corticocollicular input-defined neural pathways for defense behaviors. Neuron 93: 33-47. CrossRef Medline

Ziv Y, Burns LD, Cocker ED, Hamel EO, Ghosh KK, Kitch LJ, El Gamal A, Schnitzer MJ (2013) Long-term dynamics of CA1 hippocampal place codes. Nat Neurosci 16:264-266. CrossRef Medline 